\title{
Sistem Navigasi Pada Balon Udara Menggunakan GPS dan Kontrol Logika Fuzzy
}

\author{
Dimas Arief Rahman K., Muhammad Rivai, dan Rudy Dikairono \\ Jurusan Teknik Elektro, Fakultas Teknologi Industri, Institut Teknologi Sepuluh Nopember (ITS) \\ Jl. Arief Rahman Hakim, Surabaya 60111 \\ e-mail:muhammad_rivai@ee.its.ac.id
}

\begin{abstract}
Abstrak-Saat ini, pesawat tanpa awak adalah sarana yang potensial untuk tujuan eksplorasi. Salah satu jenis pesawat tanpa awak adaah balon udara. Balon udara sangat cocok digunakan untuk eksporasi pada kecepatan dan ketinggian yang rendah. Hal yang penting dalam pengembangan balon udara sebagai sarana eksplorasi adalah sistem navigasi. Sistem navigasi dapat mengarahkan balon udara ke tujuan yang ditentukan secara otomatis. Parameter yang diperlukan dalam sistem navigasi adalah informasi posisi dan arah objek yang akan dikontrol. Terdapat banyak metode sistem navigasi. Salah satunya adalah metode sistem navigasi dengan menggunakan GNSS (Global Navigation Satellite System) dan kompas. Metode ini menggunakan sensor GNSS mengetahui posisi, sedangkan kompas digunakan untuk mengetahui arah. Di dalam sistem ini digunakan filter kuarternion berbasis AHRS (Attitude and Heading Reference System) untuk mengkompensasi pembacaan data kompas tehadap kemiringan sensor. Dari data posisi dan arah yang didapatkan akan diolah menjadi informasi jarak dan derajat arah balon terhadap waypoint. Kemudian, informasi jarak dan derajat arah tersebut diolah untuk menggerakkan motor pada balon dan megarahkan balon pada waypoint. Sistem ini menggunakan sensor GPS berbasis GNSS (Global Navigation Satellite System) untuk mengetahui posisi, sensor kompas berbasis IMU (Inertial Measurement Unit) untuk mengetahui arah, dan kontrol logika fuzzy sebagai pengatur kecepatan motor kemudi untuk pergerakan balon. Pada metode ini, akurasi dari sensor GNSS berkisar antara 9,5 sampai 20 meter. Galat maksimum dari kompas dengan kompensasi kemiringan adalah $7 \%$. Terjadi osilasi pada arah Utara dengan simpangan berkisar antara 50-90 derajat dan arah Barat dengan simpangan sebesar 20-50 derajat.
\end{abstract}

Kata Kunci- Navigasi, Balon udara, Waypoint.

\section{PENDAHULUAN}

$\mathrm{P}$ ENGEMBANGAN sistem navigasi Unmanned Aerial Vehicle (UAV) untuk keperluan pemantauan dan eksplorasi semakin meningkat. Jenis UAV yang sering digunakan untuk keperluan ini adalah quadcopter dan pesawat fixed wing. Quadcopter memiliki bentuk yang ringkas sehingga dapat terbang di tempat yang sempit dan kecil. Pesawat fixed wing sering digunakan untuk pemetaan area yang luas karena strukturnya yang aerodinamis sehingga dapat terbang lebih lama daripada quadcopter.

Namun penggunaan kedua wahana tersebut kurang cocok untuk keperluan pemantauan dan eksplorasi. Quadcopter memiliki jangka terbang dan jarak tempuh yang pendek karena menggunakan perputaran rotor sebagai gaya angkatnya sehingga boros dalam penggunaan daya. Pesawat fixed wing jangka terbang dan jarak tempuh yang panjang, namun mempunyai kecepatan terbang yang tinggi. Selain itu, pesawat fixed wing membutuhkan landasan pacu untuk lepas landas dan mendarat. Pesawat fixed wing juga memerlukan angin yang berlawanan arah agar pesawat dapat terangkat sehingga menjadikan pesawat ini harus tetap bergerak untuk dapat terbang.

Salah satu pilihan UAV alternatif untuk keperluan pemantauan dan eksplorasi adalah balon udara. Balon udara sangat cocok digunakan untuk aplikasi ekplorasi dalam kecepatan dan ketinggian yang rendah [1]. Gaya angkat balon udara menggunakan gas helium, sehingga balon udara dapat terbang lebih lama dan dengan jarak yang jauh. Balon udara juga tidak memerlukan landasan pacu untuk dapat terbang. Oleh karena itu pada tugas akhir ini merancang dan merealisasikan sistem navigasi balon udara menggunakan GPS (Global Posistioning System) dan kompas sehingga balon udara dapat melakukan navigasi secara otomatis menuju waypoint. Dengan sistem navigasi otomatis, balon udara dapat melakukan monitoring dan eksplorasi tanpa bantuan operator.

Harapan dari teknologi ini adalah balon udara dapat bergerak dengan sistem navigasi berbasis waypoint secara otomatis untuk untuk keperluan pemantauan dan eksplorasi.

\section{DASAR TEORI}

\section{A. Sensor IMU (Inertial Measurement Unit)}

IMU adalah singkatan dari Inertial Measurement Unit, adalah sebuah sensor yang digunakan untuk mengukur sudut roll, sudut pitch dan sudut yaw. Ketiga sudut ini menentukan orientasi dari sebuah pesawat udara pada saat terbang relatif terhadap bumi. Dalam mengukur sudut orientasi pesawat udara, IMU memerlukan tiga sensor pendukung yaitu gyroscope, accelerometer, magnetometer. Sensor IMU adalah sensor gabungan yang terdiri dari sensor gyro 3 sumbu, sensor accelerometer 3 sumbu, sensor magnetometer 3 sumbu.

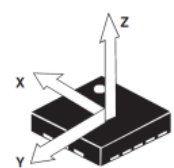

Acceleronter

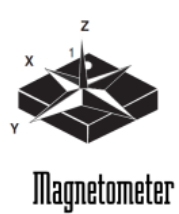

Gambar 1. Komponen sensor IMU

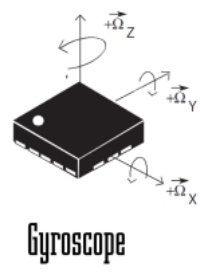

B. Akselerometer
Akselerometer adalah sensor yang digunakan untuk mengukur percepatan suatu objek. Akselerometer dapat mengukur percepatan dinamis dan statis [2]. Pengukuran 
percepatan dinamis adalah pengukuran percepatan pada objek yang bergerak, sedangkan pengukuran percepatan statis adalah pengukuran percepatan gravitasi bumi. Akselerometer dapat digunakan untuk mengukur sudut kemiringan (tilt).

Data yang diperoleh modul sensor akselerometer adalah data mentah percepatan gravitasi yang direpresentasikan dalam signed integer 16 bit. Pada perancangan tugas akhir ini, skala penuh yang dipilih adalah $8 \mathrm{~g}$ artinya data mentah sejumlah 65536 mewakili kecepatan sudut mulai 0g hingga 8g. Sensitifitas modul sensor saat skala penuh ini adalah $4 \mathrm{mg} /$ digit.

\section{Magnetometer}

Magnetometer pada sensor IMU dapat mendeteksi medan magnet bumi sehingga dapat dijadikan acuan pada kompas digital. Sensor kompas digital dan sensor magnetometer pada hakikatnya memiliki prinsip kerja yang sama. Sensor kompas digital merupakan modul sensor magnetometer dengan keluaran berupa sudut yang menyatakan arah hadap. Sedangkan sensor magnetometer keluarannya berupa besar medan magnet bumi yang diukur dalam tiga sumbu yang dapat digunakan untuk menentukan sudut arah hadap dengan rumusan tertentu [3].

Data yang diperoleh modul sensor magnetometer adalah data mentah gaya medan magnet bumi yang direpresentasikan dalam signed integer 16 bit. Di perancangan, skala penuh yang dipilih adalah 8,1 gauss artinya data mentah sejumlah 65536 mewakili gaya medan magnet bumi mulai 0 gauss hingga 8,1 gauss.

\section{Giroskop}

Giroskop digunakan untuk mengukur orientasi berdasarkan prinsip momentum sudut. Giroskop mengukur kecepatan sudut kerangka acuan inersia. Sudut orientasi berupa gerak roll, pitch, dan yaw didapatkan dengan mengintegrasikan kecepatan sudut. Sehingga hasil giroskop adalah percepatan sudut.

Giroskop berbeda dengan akselerometer dan kompas. Akselerometer mengukur gerakan linear acuan gravitasi. Akselerometer dapat memberikan pengukuran sudut kemiringan (tilt) akurat ketika suatu sistem dalam keadaan diam (statis). Saat sistem berotasi atau bergerak, akselerometer tidak dapat mengikuti pergerakan yang cepat dikarenakan responnya lambat dan memiliki noise, sehingga tidak dapat digunakan untuk pengukuran sudut orientasi dalam kendaraan udara.

Sedangkan kompas mengukur gerakan linear dengan acuan medan magnet bumi. Kompas dapat mengukur gerak yaw atau arah mata angin namun tidak dapat mengukur gerak roll dan pitch.

Keluaran giroskop berupa data kecepatan sudut. Kecepatan sudut adalah besaran vektor yang menyatakan frekuensi sudut suatu benda terhadap sumbu putarnya. Satuan untuk kecepatan sudut adalah radian per detik.

\section{E. Algoritma Magdwick AHRS}

Madgwick AHRS adalah metode untuk proses orientasi dari sensor IMU dengan mengunakan alogaritma gradient descent untuk mengestimasi nilai orientasi dari ketiga sumbu yang ada pada giroskop, akselerometer dan magnetometer. Dimana diketahui bahwa giroskop dan magnetometer pada IMU mempunyai nilai drift. Drift adalah pergeseran nilai derajat dari sumbu awal. Pada metode ini sudut-sudut euler diubah menjadi Kuaternion [4].
Konsep dasar dari Magwick AHRS adalah mencari antara relatife frame atau yang biasa disebut perpindahan frame. Contoh dapat dilihat pada gambar di atas frame A relatife terhadap frame B. Dimana nilai perpindahan frame A ke frame B dapat direpresentasikan dalam bentuk kuaternion seperti persamaan 1 .

$$
\begin{gathered}
{ }_{B}^{A} \hat{q}=[q 0 q 1 q 2 q 3] \\
=\left[\cos \frac{\theta}{2}-r x \sin \frac{\theta}{2}-r y \sin \frac{\theta}{2}-r z \sin \frac{\theta}{2}\right] \\
{ }_{B}^{A} \hat{q} *={ }_{A}^{B} \hat{q}=[q 0-q 1-q 2-q 3]
\end{gathered}
$$

Bahwa untuk mencari nilai matrik yang baru, kedua matrik tersebut dikalikan dengan aturan cross product dimana dengan mengunakan aturan Hamilton. Seperti persamaan 3.

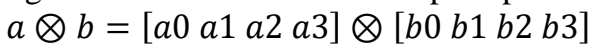

$$
=\left[\begin{array}{llll}
a_{0} b_{0} & -a_{1} b_{1} & -a_{2} b_{2} & -a_{3} b_{3} \\
a_{0} b_{1} & +a_{1} b_{0} & +a_{2} b_{3} & -a_{3} b_{2} \\
a_{0} b_{2} & -a_{1} b_{3} & +a_{2} b_{0} & +a_{3} b_{1} \\
a_{0} b_{3} & +a_{1} b_{2} & -a_{2} b_{1} & +a_{3} b_{0}
\end{array}\right]^{T}
$$

Pada gambar 2 dijelaskan alur dari metode madgwick. Untuk mengetahui representasi pergeserah frame berdasarkan sumbu garis normal gravitasi bumi menggunakan persamaan gradient decent. Dimana alogaritma gradient decent mempunyai fungsi seperti persamaan (4). Dengan demikian apabila di-cross product ketiga quaternion tersebut akan menghasilkan matrik baru (8).

$$
\begin{gathered}
f\left({ }_{E}^{S} \hat{q}, E_{\hat{d}}, S_{\hat{S}}\right)={ }_{E}^{S} \hat{q} * \otimes E_{\hat{d}} \otimes{ }_{E}^{S} \hat{q}-S_{\hat{S}} \\
{ }_{E} \hat{q}=\left[\begin{array}{ll}
q 1-q 2-q 3-q 4
\end{array}\right] \\
E_{\hat{g}}=\left[\begin{array}{lll}
0 & 0 & 0
\end{array}\right] \\
S_{\hat{a}}=\left[\begin{array}{ll}
0 \text { axayaz }
\end{array}\right] \\
\mathrm{f}_{\mathrm{g}}\left({ }_{E}^{S} \hat{q}, S_{\hat{a}}\right)=\left[\begin{array}{c}
2(q 2 q 4-q 1 q 3)-a x \\
2(q 1 q 2+q 3 q 4)-a y \\
2\left(\frac{1}{2}-q_{2}{ }^{2}-q_{3}{ }^{2}\right)-a z
\end{array}\right]
\end{gathered}
$$

Setelah proses untuk mencari nilai $f$, kemudian dicari hasil dari matrik jacobi sesuai degan persamaan (9).

$$
\mathrm{Jg}_{\mathrm{g}}\left({ }_{E}^{S} \widehat{q}\right)=\left[\begin{array}{cccc}
-2 q 3 & 2 q 4 & -2 q 1 & 2 q 2 \\
2 q 2 & 2 q 1 & 2 q 4 & 2 q 3 \\
0 & -4 q 2 & -4 q 3 & 0
\end{array}\right]
$$

Kemudian setelah kedua matrik $\mathrm{f}$ dan $\mathrm{J}$ telah didapatkan hasil.Untuk mencari nilai dari matrik gradient decent adalah sesuai dengan persamaan (10).

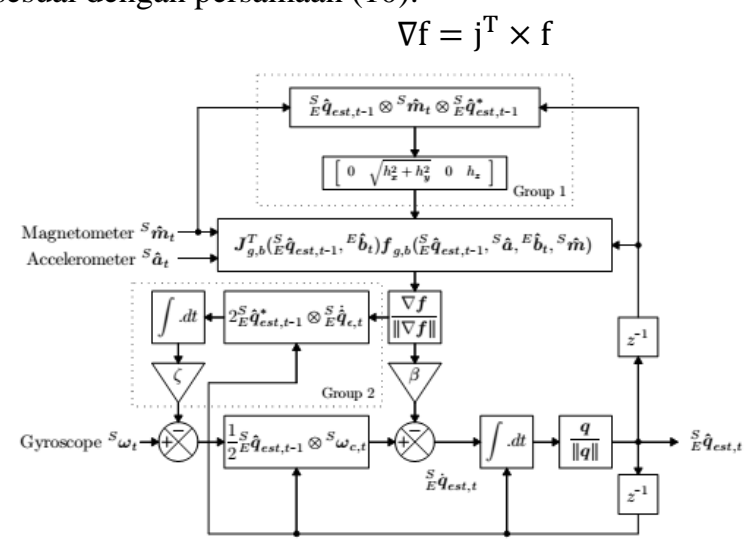

Gambar 2. Blok Diagram Magwick AHRS

Untuk mencari nilai estimasi dari kuaternion, kuaternion pada giroskop dikurangkan dengan hasil kuaternion pada proses alogaritma gradient decent yang sudah dibagi dengan 
nilai normalisasi dan dikalikan dengan nilai pembobotan (beta), sesuai dengan persamaan (11).

$$
{ }_{\mathrm{E}}^{\mathrm{S}} \dot{\mathrm{q}} \mathrm{est}, \mathrm{t}={ }_{\mathrm{E}}^{\mathrm{S}} \dot{\mathrm{q}} \omega, \mathrm{t}-\beta \frac{\nabla \mathrm{f}}{\|\nabla \mathrm{f}\|}
$$

Untuk mencari nilai $\beta$ atau pembobotan dapat menggunakan persamaan (12).

$$
\beta=\left\|\frac{1}{2} \hat{q} \otimes\left[0 \bar{\omega}_{\text {max }} \bar{\omega}_{\text {max }} \bar{\omega}_{\text {max }}\right]\right\| \sqrt{\frac{3}{4}} \bar{\omega}_{\text {max }}
$$

\section{F. Kuarternion}

Dalam matematika, Kuaternion merupakan perluasan dari bilangan-bilangan kompleks yang tidak komutatif, dan diterapkan dalam mekanika tiga dimensi. Kuaternion ditemukan oleh ahli matematika dan astronomi Inggris, William Rowan Hamilton, yang menurunkan aritmatika kompleks ke kuaternion [5].

Sebagai himpunan, kuaternion berlambang $\mathbf{H}$ (dinotasikan sesuai orang yang menemukannya Hamilton), sama dengan $\mathbf{R}^{4}$ yang merupakan ruang vektor bilangan riil empat dimensi. H memiliki tiga macam operasi: pertambahan, perkalian skalar dan perkalian kuaternion. Elemen-elemen kuaternion ditandakan sebagai $l, i, j$ dan $k(i, j$ dan $k$ adalah komponen imaginer), dan dapat ditulis sebagai kombinasi linear, $a+b i+c j+d k(a, b, c$, dan $d$ adalah bilangan riil).

\section{G. Sudut Euler}

Sudut Euler merepresentasikan orientasi tiga dimensi dari suatu objek menggunakan kombinasi tiga rotasi sumbu yang berbeda. Informasi orientasi menggunakan sudut Euler lebih sederhana daripada kuarternion. Rotasi sudut Euler pada sumbu $\mathrm{x}, \mathrm{y}$, dan $\mathrm{z}$ dilambangkan dengan nama roll $(\Phi)$, pitch $(\theta)$, dan yaw $(\psi)$.

Keluaran dari Algoritma Magwick AHRS adalah berupa sudut Euler. Algoritma tersebut memproses data mentah sensor IMU dalam representasi kuarternion. Berikut ini adalah persamaan untuk mengkonversi satuan kuarternion menjadi sudut Euler [6]:

$$
\left[\begin{array}{c}
\Phi \\
\theta \\
\psi
\end{array}\right]=\left[\begin{array}{c}
\operatorname{atan} 2\left(2\left(q_{0} q_{1}+q_{2} q_{3}\right), 1-2\left(q_{1}^{2}+q_{2}^{2}\right)\right) \\
\arcsin \left(2\left(q_{0} q_{1}-q_{2} q_{3}\right)\right) \\
\operatorname{atan} 2\left(2\left(q_{0} q_{3}+q_{1} q_{2}\right), 1-2\left(q_{2}^{2}+q_{3}^{2}\right)\right)
\end{array}\right]
$$

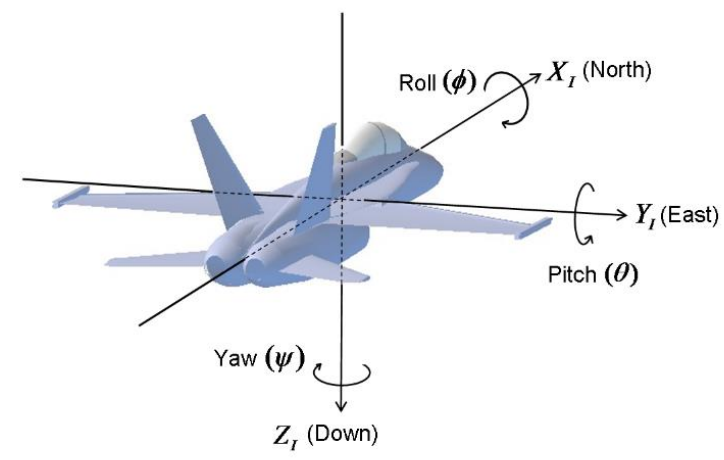

Gambar 3. Rotasi sudut Euler

\section{H. Sensor GNSS (Global Navigation Satellite System)}

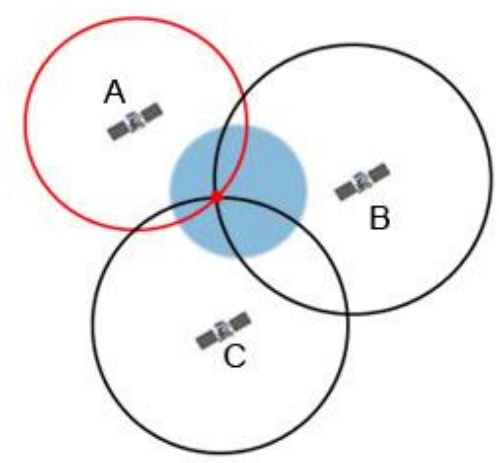

Gambar 4. Metode trilaterasi

GNSS (Global Navigation Satellite System) merupakan suatu metode pengoperasian satelit yang terdiri dari gabungan beberapa sistem satelit navigasi seperti GPS (Amerika), GLONASS (Rusia), Galileo (Uni-Eropa), dan Beidou (Cina). GNSS disediakan untuk kepentingan sipil maupun militer di seluruh dunia. GNSS menyediakan informasi posisi, ketinggian, kecepatan, dan waktu dari receiver, sehingga memungkinkan pengguna untuk mengetahui lokasi tepat dimanapun di permukaan bumi.

Pada sistem navigasi satelit GPS, hanya satelit-satelit GPS saja yang dapat menyediakan informasi mengenai posisi, ketinggian, kecepatan, dan waktu dari receiver. Sedangkan pada GNSS, ia akan menggabungkan sistem navigasi satelit yang ada (misalnya GPS dan GLONASS) sehingga sinyal satelit yang diterima oleh suatu receiver semakin banyak. Semakin banyak sinyal satelit yang ditangkap oleh receiver, semakin banyak pula data yang didapat, sehingga mempengaruhi tingkat ketelitian informasi yang dibutuhkan.

Informasi posisi didapatkan sensor GNSS dengan metode trilaterasi. Metode trilaterasi akan menghitung jarak objek ke setiap satelit (minimal 3 satelit). Dari penghitungan jarak tersebut akan didapatkan posisi dari objek berupa koordinat latitude dan longitude.

\section{Logika Fuzzy}

Logika fuzzy adalah metodologi sistem kontrol pemecahan masalah, yang cocok untuk diimplementasikan pada sistem, mulai dari sistem yang sederhana, sistem kecil, embedded system, jaringan PC, multi-channel atau workstation berbasis akuisisi data, dan sistem kontrol. Metodologi ini dapat diterapkan pada perangkat keras, perangkat lunak, atau kombinasi keduanya [7].

\section{J. Operasi Himpunan Fuzzy}

Operasi himpunan fuzzy diperlukan untuk proses inferensi atau penalaran. Dalam hal ini yang dioperasikan adalah derajat keanggotaanya. Derajat keanggotaan sebagai hasil dari operasi dua buah himpunan fuzzy disebut sebagai fire strength atau $\alpha$ predikat.

Ada beberapa hal yang perlu diketahui dalam memahami sistem fuzzy, yaitu variabel fuzzy, himpunan, dan semesta pembicaraan. Domain himpunan fuzzy adalah keseluruhan nilai yang diizinkan dalam semesta pembicaraan dan boleh dioperasikan dalam suatu himpunan fuzzy [8] [9]. 


\section{PERANCANGAN SISTEM}

\section{A. Blok Diagram Sistem}

Pada sistem navigasi yang dirancang (Gambar 5), sensor GNSS dan kompas digunakan untuk mengetahui posisi balon dan arah hadap balon terhadap waypoint. Informasi tersebut kemudian dimasukkan pada mikrokontroller (Arduino Mega) sehingga data dapat diproses pada kontrol logika fuzzy untuk menggerakkan motor balon. Motor tersebut akan mengarahkan balon ke koordinat waypoint. Pada sistem ini, waypoint dapat diinputkan dari antarmuka user dengan mikrokontroller menggunakan komunikasi serial.

\section{B. Kalibrasi Magnetometer}

Ketika mengakuisisi data magnetometer untuk dikonversi menjadi heading, perlu diketahui jenis kesalahan yang mempengaruhi pembacaan sensor.

Heading dapat ditentukan melalui penggunaan magnetometer dan akselerometer tiga sumbu yang tersedia di sensor IMU. Namun sistem kompas harus diterapkan dengan benar dan dapat mngkompensasi pengaruh elevasi dan kemiringan sudut.

Tanpa kalibrasi, data magnetometer akan terdistorsi sehingga pembacaan menjadi tidak tepat. Untuk melakukan kalibrasi dilakukan penghitungan offset yaitu dengan persamaan:

$$
\begin{aligned}
& \alpha=\frac{x_{\text {max }}+x_{\text {min }}}{2} \\
& \beta=\frac{y_{\text {max }}+y_{\text {min }}}{2} \\
& \gamma=\frac{z_{\text {max }}+z_{\text {min }}}{2}
\end{aligned}
$$

Hasil dari persamaan di atas adala besar offset pada sumbu x, y, dan z. Kemudian pembacaan setiap sumbu magnetometer dikurangkan dengan hasil tersebut.

$$
\begin{aligned}
& M x=M x-\alpha \\
& M y=M y-\beta \\
& M z=M z-\gamma
\end{aligned}
$$

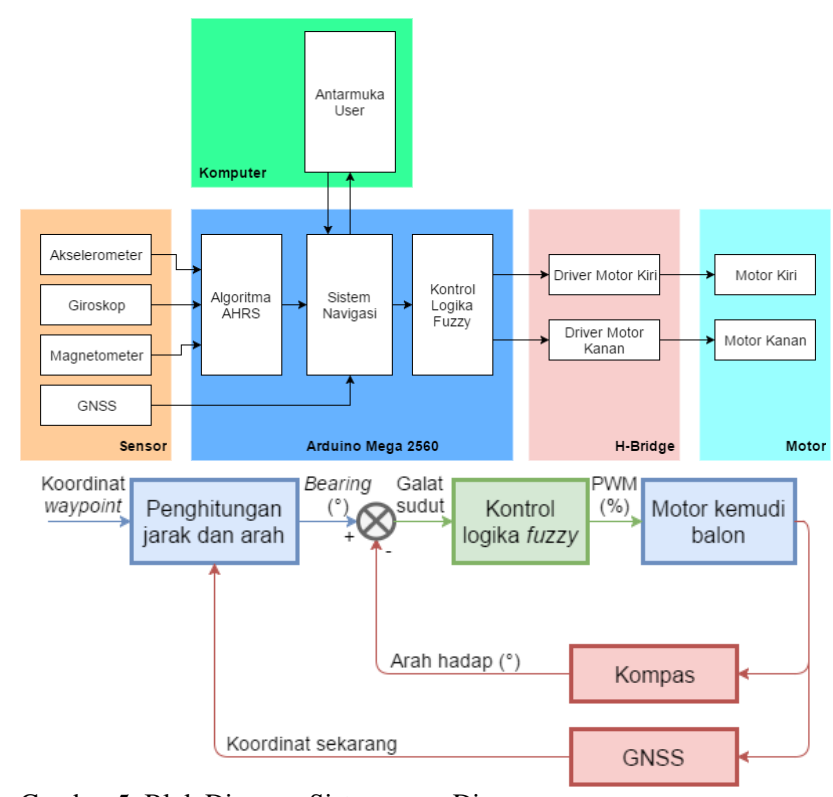

Gambar 5. Blok Diagram Sistem yang Dirancang

\section{Metode Pengukuran Geodistance}

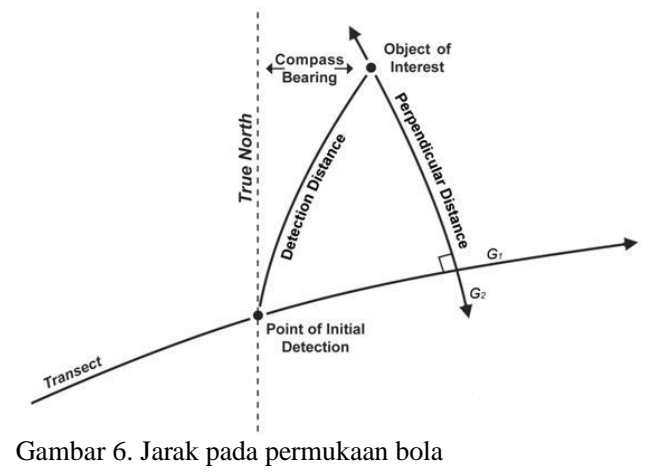

Geodesic Distance adalah jarak antara dua titik koordinat pada permukaan bumi. Gambar diatas merupakan ilustrasi dari pengukuran jarak pada permukaan bola. Permukaan bumi tidak planar/datar melainkan berbentuk bola, sehingga pengukuran jarak antara dua titik koordinat tidak dapat dilakukan dengan metode planar. Untuk mengukur jarak pada permukaan elips bumi digunakan persamaan Haversine. Persamaan tersebut menghitung jarak terpendek antara dua titik koordinat pada permukaan bumi. Persamaan Haversine dinyatakan melalui persamaan berikut:

$$
\begin{gathered}
a=\sin ^{2}\left(\frac{\Delta \varphi}{2}\right)+\cos \varphi_{1} \cdot \cos \varphi_{2} \cdot \sin ^{2}\left(\frac{\Delta \lambda}{2}\right) \\
c=2 \cdot \operatorname{atan} 2(\sqrt{a}, \sqrt{1-a}) \\
d=R \cdot c
\end{gathered}
$$

Dimana :

$$
\begin{aligned}
& \varphi=\text { Latitude dalam radian } \\
& \lambda=\text { Longitude dalam radian } \\
& c=\text { Jarak angular } \\
& R=\text { Jari }- \text { jari bumi }(6371 \mathrm{~km}) \\
& d=\text { Jarak pada permukaan bumi }
\end{aligned}
$$

\section{Metode Pengukuran Geobearing}

Secara umum, relative bearing adalah sudut antara arah hadap objek (heading) dengan target. Sedangkan magnetic bearing adalah sudut antara arah utara dengan target.

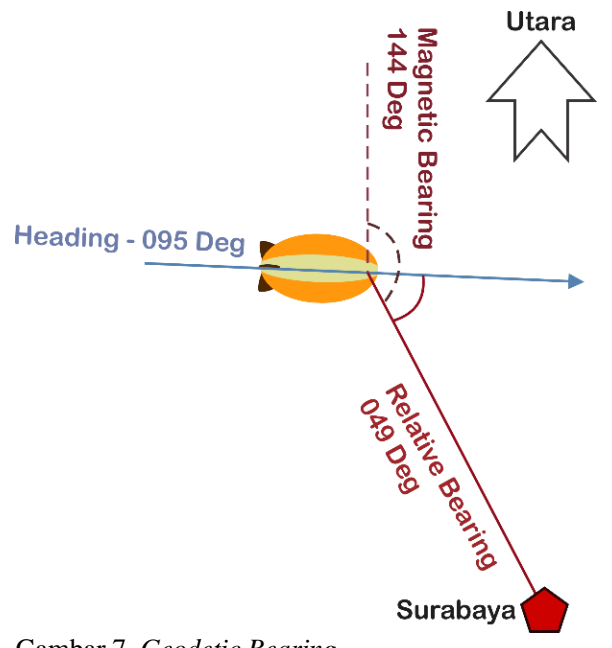

Gambar 7. Geodetic Bearing

Persamaan dibawah ini adalah persamaan yang diperlukan untuk menghitung magnetic bearing jika ditarik garis lurus dari posisi awal menuju target sepanjang busur bumi: 
$\theta=\operatorname{atan} 2\left(\sin \Delta \lambda \cdot \cos \varphi_{2}, \cos \varphi_{1} \cdot \sin \varphi_{2}-\sin \varphi_{1} \cdot \cos \varphi_{2} \cdot\right.$ $\cos \Delta \lambda)$

$$
\begin{aligned}
& \text { Dimana : } \\
& \varphi=\text { Latitude dalam radian } \\
& \lambda=\text { Longitude dalam radian } \\
& \theta=\text { Bearing }
\end{aligned}
$$

\section{E. Sistem Navigasi}

Langkah awal yang dilakukan oleh sistem adalah inisialisasi sensor. Sensor yang digunakan adalah sensor GNSS dan sensor kompas. Kemudian setelah itu dilakukan inisialisasi motor. Ada 2 motor yang digunakan sebagai motor kemudi yang berada di samping balon. Setelah inisialisasi sensor dam motor, dilakukan pengambilan data waypoint yang dilakukan oleh user pada antarmuka. Data waypoint disimpan pada memori, kemudian balon udara tetap standby sampai tombol start ditekan.

Ketika tombol start ditekan, maka balon udara akan melakukan perhitungan geodistance (jarak posisi sekarang dan posisi target) dan geobearing (sudut antara posisi sekarang dan posisi target relatif tehadap arah utara). Geobearing akan dibandingkan dengan heading (sudut arah hadap balon udara relatif tehadap arah utara) yang terdeteksi dari sensor kompas. Balon udara akan mengetahui berapa galat sudut heading terhadap geobearing. Nilai galat tersebut dimasukkan pada kontrol logika fuzzy. Kemudian balon udara akan mengaktifkan motor kemudi yang kecepatannya diatur dari keluaran kontrol logika fuzzy untuk bergerak ke arah tujuan berdasarkan galat sudut heading terhadap geobearing. Pergerakan tadi akan mempertahankan nilai galat heading terhadap geobearing bernilai nol sehingga track yang akan dilalui oleh balon terarah menuju ke waypoint. Hal tersebut akan dilakukan berulang selama geodistance kurang dari niai toleransi jarak tujuan yang ditentukan oleh user.

Jika nilai geodistance lebih dari nilai toleransi jarak tujuan, balon udara akan berhenti karena posisi yang terdeteksi oleh balon udara dianggap sudah mencapai area waypoint. Proses navigasi oleh balon udara dinyatakan selesai.

\section{F. Logika Fuzzy}

Perhitungan kecepatan motor dilakukan dengan menggunakan bantuan logika fuzzy untuk mempermudah proses penentuan. Pada sistem yang dirancang digunakan sebuah Fuzzy Interference System (FIS), yaitu FIS untuk kontrol motor samping. Untuk FIS motor samping dirancang fuzzy 2 input 2 output. Input FIS berupa derajat sudut arah dari heading dan bearing, sedangkan keluaran berupa sinyal PWM (Pulse Width Modulation) untuk motor kanan dan kiri.

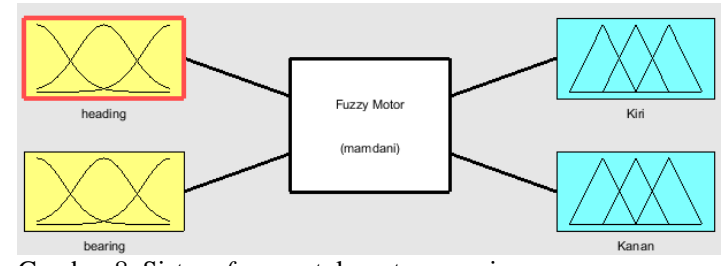

Gambar 8. Sistem fuzzy untuk motor samping

\section{HASIL DAN ANALISA}

\section{A. Realisasi Desain Balon Udara}

Pada tugas akhir ini digunakan dua balon udara air swimmer yang diisi dengan helium dengan ukuran panjang 110 $\mathrm{cm}$, lebar $60 \mathrm{~cm}$, dan tinggi $60 \mathrm{~cm}$. Volume dari balon udara ini adalah $0,1274 \mathrm{~m}^{3}$. Dua balon udara air swimmer mempunyai volume untuk diisi helium sebesar $0,2548 \mathrm{~m}^{3}$. Sehingga balon udara air swimmer dengan volume $0.2548 \mathrm{~m}^{3}$ dapat mengangkat beban sekitar 240 gram jika diisi penuh gas helium.

Setelah dilakukan pengujian, Beban maksimal balon udara adalah 233 gram dan titik tengah gravitasi balon pada pada jarak $30 \mathrm{~cm}$ dari depan balon, $24 \mathrm{~cm}$ dari kanan balon, dan $36 \mathrm{~cm}$ dari kiri balon.

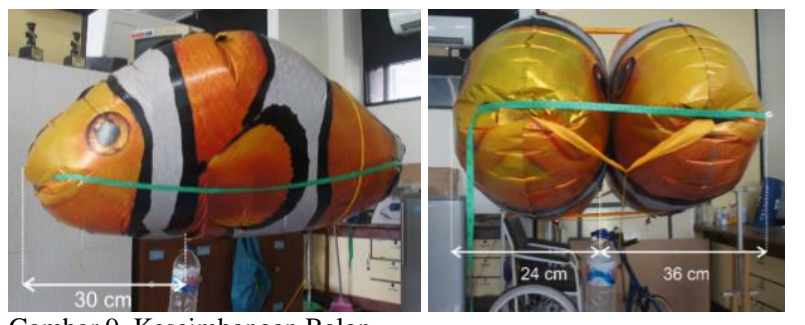

Gambar 9. Keseimbangan Balon

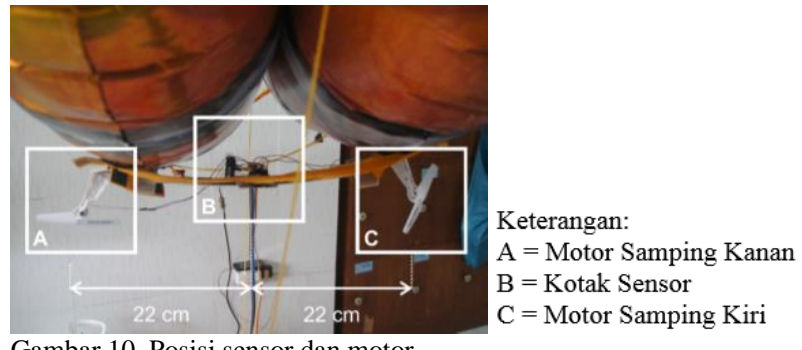

Gambar 10. Posisi sensor dan motor

\section{B. Pengujian GNSS}

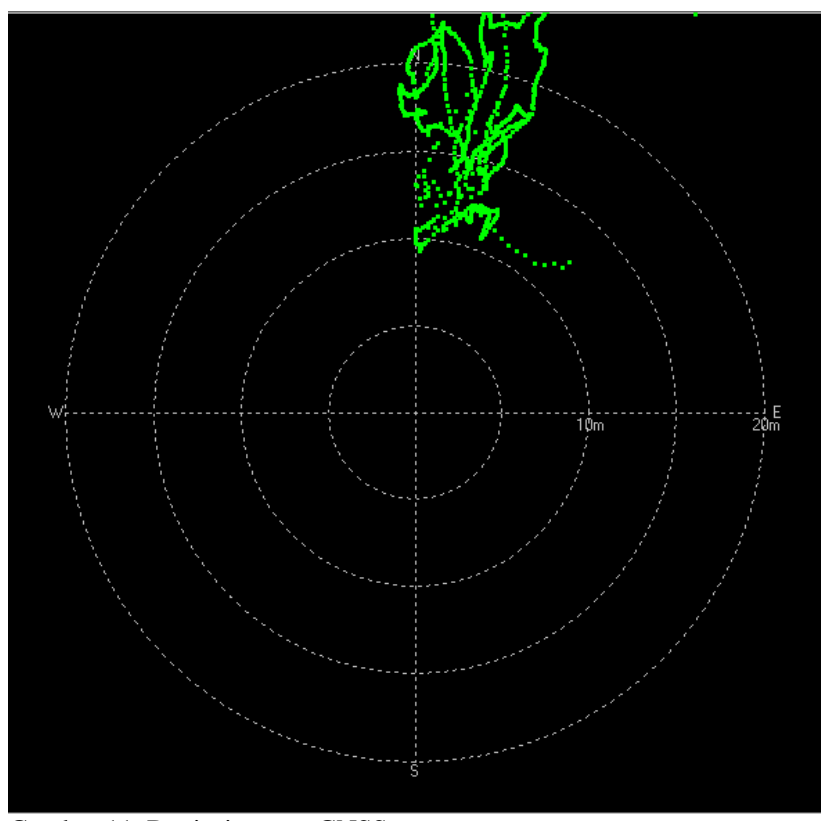

Gambar 11. Deviasi sensor GNSS 


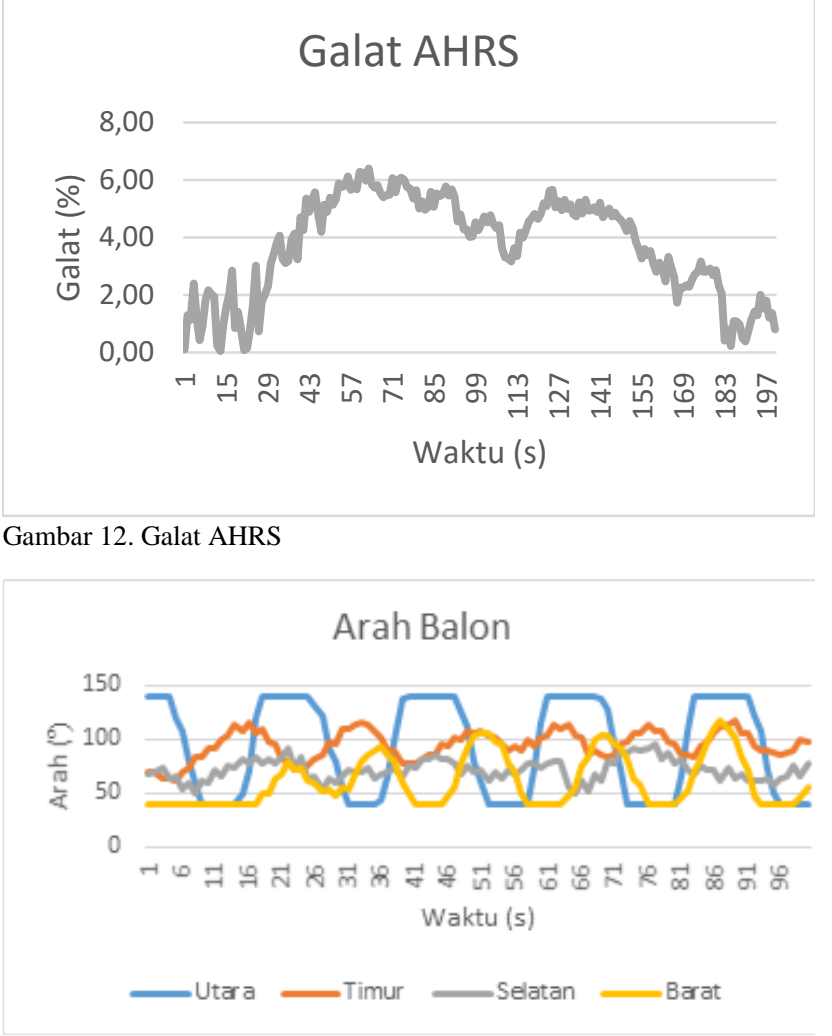

Gambar 13. Grafik Arah Balon

Gambar 11 menunjukkan hasil pengujian pengukuran posisi sensor GNSS. Hasil yang didapatkan menunjukkan posisi yang terdeteksi rata-rata berada pada rentang 9,5-20 meter dari posisi sebenarnya. Hal ini normal karena sensor GNSS yang digunakan memiliki spesifikasi akurasi 10-25 meter.

\section{Pengujian AHRS}

Gambar 12 menunjukkan bahwa kompensasi kemiringan menggunakan filter kuarternion berbasis AHRS menghasilkan error permbacaan derajat arah yang relatif kecil. Error tertinggi adalah 6,41\%.

\section{Pengujian Sistem Navigasi}

Pada gambar 13 terlihat bahwa respon sistem masih berosilasi untuk mempertahankan arah Utara dan Barat. Simpangan osilasi arah Utara berkisar antara 50-90 derajat. Sedangkan simpangan osilasi arah barat sebesar 20-50 derajat. Namun untuk arah Timur dan Selatan, sistem tidak menghasilkan galat yang terlalu besar.

\section{KESIMPULAN}

Telah dibuat dan dirancang sistem navigasi pada balon udara menggunakan GPS dan kontrol logika fuzzy. GPS digunakan untuk mendeteksi posisi didukung dengan kompas untuk mendeteksi arah hadap. Kontrol logika fuzzy digunakan pada sistem pengaturan motor kemudi untuk pergerakan balon. Berdasarkan pengujian beban yang telah dilakukakan didapatkan titik tengah gravitasi balon pada pada jarak $40 \mathrm{~cm}$ dari depan balon, $24 \mathrm{~cm}$ dari kanan balon, dan $36 \mathrm{~cm}$ dari kiri balon. Berat maksimum yang dapat diangkat oleh balon adalah
233 gram. Akuisisi data sensor IMU untuk mengetahui derajat arah hadap menggunakan algoritma AHRS dapat menghasilkan kesalahan pengukuran kurang dari 7\%. Pengukuran posisi objek menggunakan sensor GNSS menghasilkan posisi berada pada rentang 9,5-20 meter dari posisi sebenarnya. Penggunaan logika fuzzy dapat diterapkan pada sistem kontrol motor kemudi untuk pergerakan balon dengan variable yang digunakan berupa galat derajat arah hadap balon udara terhadap derajat bearing. Terjadi osilasi untuk mempertahankan arah Utara dengan simpangan berkisar antara 50-90 derajat dan arah Barat dengan simpangan sebesar 20-50 derajat.

\section{DAFTAR PUSTAKA}

[1] J. Rao, Z. Gong, J. Luo and S. Xie, "A flight control and navigation system of a small size unmanned airship," in IEEE Int. Conf. Mechatronics and Automation, Canada, 2005.

[2] P. Chaklos, "RC Blimp, Remote Control Airship, Inflatables," Above \& Beyond Inc, 15 Januari 2010. [Online]. Available:

http://www.advertisingballoons.com/remote-control-blimps.htm. [Accessed 15 Juni 2016].

[3] W. Storr, "Hall Effect Sensor and How Magnets Make It Works," Electronics-tutorials.ws, 14 April 2016. [Online]. Available: http://www.electronics-tutorials.ws/electromagnetism/hall-effect.html. [Accessed 15 Juni 2016].

[4] S. O. H. Madgwick, A. J. L. Harrison and R. Vaidyanathan, "Estimation of IMU and MARG orientation using a gradient descent algorithm," in 2011 IEEE International Conference on Rehabilitation Robotics, Zurich, 2011.

[5] W. R. Hamilton, Elements of Quaternions, Longmans: Green \& Company, 1866.

[6] L. Brits, "Conversion between quaternions and Euler angles," Wikimedia Foundation, Inc, 11 November 2007. [Online]. Available: https://en.wikipedia.org/wiki/Conversion_between_quaternions_and_E uler_angles. [Accessed 15 Juni 2016].

[7] F. Dai, W. Gao, N. Kushida and L. Shang, "Fuzzy control for the autonomous airship," in 6th IEEE Conference on Industrial Electronics and Applications, Beijing, 2011.

[8] S. Kusumadewi, Artificial Intelligence (Teknik dan Aplikasinya), Yogyakarta: Graha Ilmu, 2003.

[9] T. Sutojo, E. Mulyanto and V. Suhartono, Kecerdasan Buatan, Yogyakarta: Andi Offset, 2011. 